\title{
The Intervention of Rural Enterprise Development Hub Project on Maize Production in Mqanduli: The Implication on Food Security Status of Maize Farmers
}

\author{
Enoch Terlumun Iortyom ${ }^{1,2}$, Sonwabo P. Mazinyo ${ }^{1}$, Werner Nel ${ }^{1}$ \\ ${ }^{1}$ Department of Geography and Environmental Science, University of Fort Hare, Private Bag X1314, Alice, 5700, \\ Eastern Cape Province, South Africa. \\ ${ }^{2}$ Department of Geography, University of Liberia, Fendall, Louisiana, P.O.Box 9020, 1000 Monrovia, 10 Liberia
}

Received: 2018-07-13 Accepted: 2019-07-30

Keywords:

RED Hub Project;

Maize Farmers;

Impact;

Food Security;

Mqanduli.

Correspondent Email:

iortyomenoch@gmail.com

\begin{abstract}
The research analyzed the impact of the Rural Enterprise Development Hub Project (RED Hub Project) on food security of maize farmers. The data were analyzed using both inferential and descriptive statistics. Values were considered to be significant statistically where the $\mathrm{P}$-value was less than 0.05 . The study reveals a significant average increase in annual yield from 39.52 bags $(50 \mathrm{~kg})$ to 87.02 bags $(50 \mathrm{~kg})$ with a percentage increase of $120.19 \%$ per maize farm ( $\mathrm{t}$-statistics of $32.7 \mathrm{t}$-value and $\mathrm{p}$-value of $<0.05)$. Also, none of the maize farmers were food secure before the RED Hub project, 1 (0.5\%) were mildly food insecure, 97 (48.5\%) were averagely food insecure, and 102 (51\%) were critically food insecure. After the RED Hub project intervention, 3.5\% (7) are food secure, 104 (52\%) are mildly food insecure, 76 (38\%) are averagely food insecure and 13 (6.5\%) critically food insecure. There was also more access and affordability of other food to meet maize farmers' nutritional needs after the project intervention. An average of $72.5(29.2 \%)$ beneficiaries and 99.3 (47.6\%) beneficiaries respectively had access to other foods to meet their nutritional needs before and after the project intervention.
\end{abstract}

(C) 2019 by the authors. This article is an open access article distributed under the terms and conditions of the Creative Commons Attribution(CC BY NC) licensehttps://creativecommons.org/licenses/by-nc/4.0

\section{Introduction}

Food insecurity and poverty is a problem most African Countries are battling to eradicate. The pattern of hunger and poverty in rural areas calls for urgent intervention (Agriculture Special Report 2013; Ndleve et al. 2013). Food security is said to be the state when people can have access to adequate, safe and nutritive food physical and affordable all the time to meet the requirements of their diet and other food options for a robust life (Joseph, 2014; Sonnino, 2016). According to Abate et al. (2017), "Food access means the ability to get food (physically, financially and socially)" whereas food utilization involves the absorption of nutrients by the body (Poppy et al., 2014).

Maize is essential in South Africa's strategy for food security, and its importance can never be overemphasized (Sinyolo et al., 2016). Maize production in South Africa is achieved using different farming systems, small scale subsistence-oriented farmers, and emerging commercial farmers (medium/large scale) predominate the system (Iortyom et al., 2018). As a result of this systems, the production is typically characterized by low yields, irrespective of farm size, the consequence is the high unit cost which leads to low output (Trefry et al., 2014).

Depending on the continent, maize as a staple food and its importance differs. There is a very high per capita consumption of maize in Southern Africa countries, which is at $85 \mathrm{~kg}$ in a year. This is in contrast to the per capita consumption rate of $27 \mathrm{~kg}$ in East and West Africa per year and $25 \mathrm{~kg}$ per capita consumption in Central Africa per year. In Lesotho, Zambia, Zimbabwe, Malawi, and South Africa, the conventional rate of maize intake is at $100 \mathrm{~kg}$ per capita per year. These consumption rates represent the overall calories of over 50\% in Lesotho, Zambia as well as Malawi, while in Zimbabwe is $43 \%$, and $31 \%$ in South Africa (Smale et al., 2011).

Maize has potential in solving deficiencies in micronutrients and promotion of dietary diversity among the populations due to its richness in vitamin A (USAID, 2011). It is the view of Onasanya and Obayelu, (2016) that cereals are known to be the primary source of food as regards achieving food security in a country. One of the most important food crops consumed in the world is maize. The other two major food crops are rice and wheat, which combined with maize provide more than $30 \%$ calories to an estimated population of 4.5 million people living in developing countries. However, maize contributes over $20 \%$ of food calories and is the principal source of food for the majority of Africans and Latin Americans. Maize consumption among human consumption is based on the proportion 
of calories it contributes to all staple cereal crops across regions. Also, as compared to other cereals, the role of maize as a source of protein and energy from all other staples is the same (Shiferaw et al., 2011).

In the USA, maize is used mostly as raw material for industries, especially as a key component in the production of bioethanol. Despite this change in demand for maize, there are states in America and countries in Asia in which maize still provides essential energy requirements. In Mesoamerica and the Andean region, maize contributes $61 \%$ and $29 \%$ respectively of calories from the staple cereals. Mexico, Guatemala, and Paraguay have high maize supplies of $986 \mathrm{kcal} /$ capita/day, $820 \mathrm{kcal} /$ capita/day and $551 \mathrm{kcal} /$ capita/day respectively (Shiferaw et al., 2011).

According to Matlou et al., (2017) in Southern Africa Community (SADC), maize is the most important source of carbohydrates for both animal and human consumption. It is also the largest locally cultivated field crop. Being the significant, highly important, and extensively cultivated grain crop, it is a main part of the diet for communities in South Africa both in rural and urban areas. South Africa is a significant contributor to maize production in the SADC region (Matlou et al., 2017; ARC, 2016). In South Africa's food security plan, maize occupies a central position alongside, sugarcane, and potatoes (Smit, 2016).

Maize is a staple and most significant grain crop in Sub-Saharan Africa with a consumption population of over 1.2 billion people, maize occupies the largest cultivated area and it is adjudged the third cereal crop is grown in Sub-Saharan Africa (Suleiman and Rosentrater, 2015). Its intake accounts for over 30\% of low-income households in the region, with its dietary energy contributing $60 \%$ while its dietary protein contributes 50\% (Aliber and Hart, 2009; Ranum, PenaRosas, and Garcia-Casal, 2014)

Cereals offer more supplementary nourishment to humankind as compared to other food options and an approximation of half the caloric requirement (Ranum et al., 2014). Maize, wheat, and rice are among many other types of cereal crops that are important and mostly consumed by humankind for food; their total consumption rate is at $94 \%$. There is a preference in the intake and usage of these cereals from one region to another; wheat is a preferred and favorite cereal in Europe, Europe, South America, North America, and Central Asia. While in Asia, the preferred cereal crop is rice with maize (Zea mays) preferred in Eastern and Southern Africa, Mexico and Central America (Ranum et al., 2014; FAOSTAT, 2015).

Maize has possibly replaced sorghum and millet in most African countries today and been the most significant economic-wise and essential cereal crop in African (Olaniyan, 2015). Maize is a staple food crop consumed by Africans with different food choices and diverse social and economic background. It is quickly replacing other conventional foods with much starch like cassava. Olaniyan, (2015) notes that maize has a taste that is increasingly accepted by the native populations; hence, its growing acceptance as a traditional cereal. Another reason for its fast acceptance is that, the nutrients provided by maize are in compacted form (Olaniyan, 2015).

Since 1994 the South Africa Government has given substantial attention to the potential impacts of rural development on food production, sustenance and well-being of its rural populace through government programmes, this necessitated the conception and implementation of various rural development policies and plans to improve food production, rural livelihoods and the promotion of sustainable rural communities (DRDLR, 2012). In addressing the high level of food insecurity, the Eastern Cape Provincial government saw the need for a long term food security agenda with the adoption of the National Comprehensive Rural Development Programme strategy and aligned to its Rural Enterprise Development Hub Project.

Rural Enterprise Development Hub Project (RED Hub Project) was launched by the Eastern Cape Provincial government in South Africa in 2012, two years after the take-off of Comprehensive Rural Development Programme. RED Hub Project is aimed at boosting primary production activities, processing and marketing those products with the rural communities. The RED Project concept is aligned to the Comprehensive Rural Development Programme (CRDP) priorities with the rural areas as the central areas of operation. The concept connects three elements of production, processing and marketing all within the community (RED Project Mission Brochure, 2013). The RED Hub project model is a frame work that provides a platform for economic activity that would eventually result to an increase in rural incomes through the production and marketing of primary grain (Maize, Sorghum and Soya beans) (Qongyo, 2015).

RED Hub project is anchored on a Community Driven Development (CDD) strategy which gives control to beneficiaries to own and decide their development. CDD alludes more to the way a strategy or an undertaking is planned and executed than to the substance of an approach or to the parts of a venture task or program (International Fund for Agricultural Development-IFAD, 2009). CDD evolved as a response to the failures of earlier programs in South Africa targeted towards poverty alleviation such as lending to agricultural institutions and integrated development programs for a geographical area. It is a strategic approach that gives community groups control to take their development decisions and to take charge of such developments.

Community Driven Development (CDD) programs in the most recent decade have been held onto as a powerful strategy for Program Based Approach (PBA) for International Development Aid delivery (Iortyom et al., 2018). Since Community Driven Development gives 
community groups a charge over their development, it is hoped that the approach would improve sustainability; improve productivity and effectiveness; enable poverty reduction to a very low scale; enable inclusive development; empowerment of the poor, social capital mobilization, and to supplement market and activities in the public sector by strengthening governance. (Dongier et al., 2003; Baird et al., 2009; Spector, 2010; Binswanger and Jacomina, 2012; Kwadwo and Peter, 2012). The core belief of CDD proponents according to Binswanger and Jacomina, (2012) is that the poor can turn into the most vital actors in their development.

Review of some aforementioned extant researches (Dongier et al., 2003; Baird, et al., 2009; Spector, 2010; Binswanger and Jacomina, 2012; Kwadwo and Peter, 2012; World Bank 2013; Obidare, 2014) shows that assessment of any Community-Driven Developmental (CDD) program is germane, may it be funded by international donor agencies, national bodies or provincial governments. In a similar vein, this paper intends to fill an important gap in the body of existing literature by examining the effectiveness of the Eastern Cape Province, designed and funded Community Driven Development RED Hub project, in the achievement of improvement in the maize crop production and on how impactful has been the change in maize crop production on the achievement of food security among maize farmers in rural communities.

\section{The Methods}

The research was carried out in South Africa at
Mqanduli Community within Eastern Cape Province. The community is named after a nearby hill and is located $30 \mathrm{~km}$ South of Mthatha and $22 \mathrm{~km}$ North of Elliotadle (Iortyom et al., 2018). Mqanduli was created in 1876 and is located between latitudes 310 49' 9" South and longitude $28046^{\prime} 42^{\prime \prime}$ East (Figure 1.) It is $752 \mathrm{~m}, 2467.19 \mathrm{ft}, 29606.32$ inches above sea level. The settlements in the area have large uneven and low levels of services. However, some settlements, especially in the heart of Mqanduli, along the major route from Vigesville to Coffee Bay, have rural service nodes with community facilities due to recent infrastructural development in the area. The population density is $268.05 / \mathrm{km} 2$, with a percentage increase of $+1.15 \%$ per year. Mqanduli economy is driven by an agricultural enterprise (DRDLR, 2015; STATSA, 2012).

The sample of respondent used for the study was selected using a multistage sampling technique. Cochran sample size formula (Cochran, 1977) was used to statistically get the sample of 200 respondents from 398 farmers who benefitted from the project at $95 \%$ confidence level with $5 \%$ margin of error in the first stage (Iortyom et al., 2018). This sampling formula has been used in corresponding studies by Assenga and Kayunze, (2016), Berhe et al., (2016), Pindiriri et al., (2016), Sharoni et al., (2016), Shoja and Choolandimi, (2016), Tesfahunegn et al., (2016), and Israr et al., (2017).

The Cochran sample size formula is as shown

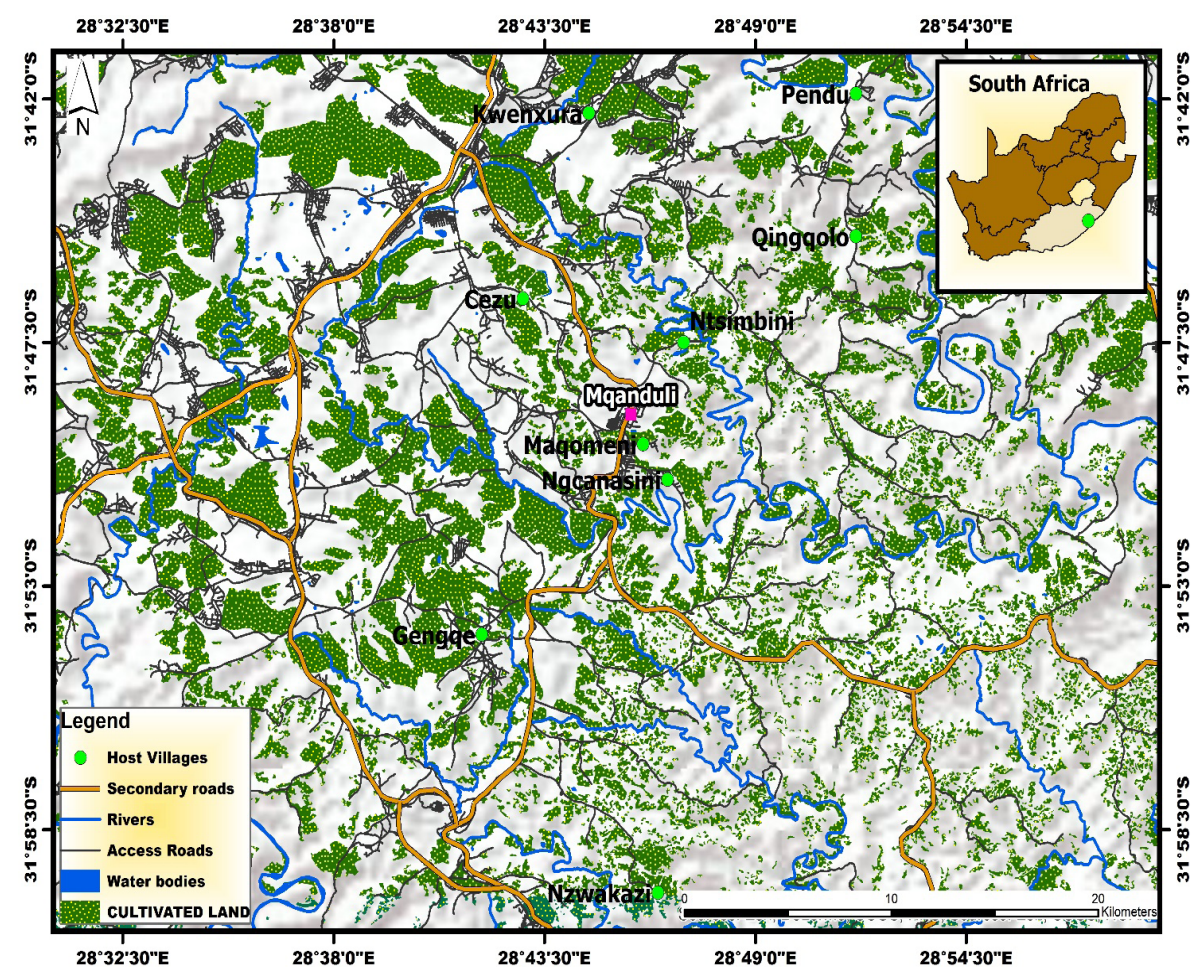

Figure 1. Map of Mqanduli showing RED Hub Project benefitting villages 
Table 1. Changes in Annual Yield per Farm in bags (50kg)

\begin{tabular}{|c|c|c|c|c|c|c|}
\hline Village & $\begin{array}{l}\text { Annual yield } \\
\text { per farm in the } \\
\text { bag }(50 \mathrm{~kg}) \\
\text { Before } \\
\overline{\mathrm{x}}_{\text {(SD) }}\end{array}$ & $\begin{array}{l}\text { Annual yield } \\
\text { per farm in } \\
\text { bag }(50 \mathrm{~kg}) \\
\text { After } \\
\overline{\mathrm{x}}_{(\mathrm{SD})}\end{array}$ & $\begin{array}{l}\text { Mean difference } \\
\text { (CI) }\end{array}$ & T statistics & p-value & $\begin{array}{l}\text { Percentage } \\
\text { change of yield } \\
\text { per farm in bags } \\
(50 \mathrm{~kg})\end{array}$ \\
\hline Ntsimbini & $45.05(10.12)$ & $106.71(23.55)$ & $61.7(52.7-70.6)$ & 14.3 & 0.000 & 136.87 \\
\hline Khwenxura & $44.27(5.70)$ & $118.46(12.11)$ & $74.2(68.6-79.8)$ & 27.3 & 0.000 & 167.45 \\
\hline Qhingqolo & $25.48(9.82)$ & $47.14(11.67)$ & $21.7(19.3-24.1)$ & 18.8 & 0.000 & 85.01 \\
\hline hhPhendu & $44.50(2.00)$ & $94.06(5.56)$ & $49.6(46.8-52.4)$ & 37.6 & 0.000 & 111.37 \\
\hline Cezu & $48.91(7.96)$ & $109.48(16.50)$ & $60.6(53.9-67.3)$ & 18.9 & 0.000 & 123.80 \\
\hline Ngcanasini & $43.94(2.60)$ & $94.17(2.89)$ & $50.2(48.8-51.6)$ & 72.8 & 0.000 & 114.31 \\
\hline Maqomeni & $41.13(5.24)$ & $93.38(8.18)$ & $52.3(48.0-56.5)$ & 25.9 & 0.000 & 127.04 \\
\hline Gengqe & $31.60(9.81)$ & $60.95(9.29)$ & $29.4(24.5-34.2)$ & 12.6 & 0.000 & 92.88 \\
\hline Nzwakazi & $28.43(8.96)$ & $50.67(9.18)$ & $22.2(19.8-24.7)$ & 18.7 & 0.000 & 78.23 \\
\hline All Villages & $39.52(10.68)$ & $87.02(27.64)$ & $47.5(44.6-50.4)$ & 32.7 & 0.000 & 120.19 \\
\hline
\end{tabular}

Note: t-test statistics. P-value $<0.05 ; 0.000=$ significant (Source: Field Survey, 2017)

$$
\mathrm{W}^{\text {Sample size }}=\frac{\frac{z^{2} \times p(1-p)}{e^{2}}}{1+\left(\frac{z^{2} \times p(1-p)}{e^{2} N \ldots \ldots,}\right)}
$$

Margin of error $=\mathrm{e}$

Z-Score (Standard Score $)=\mathrm{Z}$

Convenience sampling was done at the second stage to determine the number of maize farmers in various villages who benefitted from RED Hub Project (Iortyom et al., 2018). Convenience sampling is a kind of non-probability sampling where members of a target population which satisfy an acceptable practical guideline, such as easy access, proximity to the geographical area, availability of the targeted population at a particular time or their disposition to participate are involved in being part of a study (Etikan et al., 2016).

These villages and the number of respondents were; Ntsimbini-21; Khwenxura-26; Qhingqolo-21; Phendu-16; Cezu-21; Ngcanasini-36; Magomeni-16; Gengqe-22; and Nzwakazi-21. The number of respondents as a result of more beneficiaries of RED Hub Project in some villages than others and also the number of participation was based on the response of beneficiaries to the invitation for the exercise. Correspondently, Oladoja, and Adeokun (2009) used the same approach for the National Fadama Development Project in Ogun State to get the required sample for their study.

A pre-tested structured interview questionnaire was tested for reliability, to ascertain if the content of the questionnaire is not above the level of the respondents before it was finally administered on the sampled population. Descriptive statistics and inferential statistics were used to examine the degree of relationships between crop yield and food security status of maize farmers in the study area, particularly in the context of the interventionist RED Hub project. The analysis was done using SPSS Statistics version 21.

The categorization of food security level was with the use of the Household Food Insecurity Access Scale (HFIAS) to determine if beneficiaries of the project are Food secure, Moderately Food Insecure, and Critically Food Insecure before and after RED Project Intervention was used. The HFIAS was analyzed concerning the Food and Nutrition Technical Assistance (FANTA) indicator guide version 3, formulated by Coates et al., (2007).

The highest score for a household is 27 (the response was 'often' to all nine questions, coded with 3) and the least score is 0 (when the response is 'no' to all occurrence questions, therefore the frequencyof-occurrence questions could be skipped). The higher the score, the more food insecure the household is considered. Households are categorized into four levels of household food insecurity (access): 1) food secure, 2) mild, 3) averagely and 4) critically food insecure (Coates et al., 2007).

\section{Results and Discussion}

The mean annual yield per farm from table 1 indicates that Ntsimbini village is 45.05 bags and 106.71 bags with $136.87 \%$ change before and after RED hub project intervention. Khwenxura village is 44.27 bags and 118.46 bags before and after the project, with a percentage change of $167.45 \%$. Qhingqolo village is 25.48 bags and 21.7 bags with $85.01 \%$ change before and after the project intervention. Phendu village is 44.50 bags and 94.06 bags respectively with $111.37 \%$ before and after the project intervention. Ngcanasini 
and Maqomeni villages are 43.94 bags and 94.17 bags, and 41.13 bags and 93.38 bags with percentage changes of $114.31 \%$ and $127.04 \%$ respectively. Gengqe village is 31.60 bags and 60.95 bags before and after the project with $92.88 \%$ change, and Nzwakazi is 28.43 bags and 50.67 bags with $78.23 \%$ change while the percentage change of annual yield in the entire study area is $120.19 \%$ with the mean annual yield of 39.52 bags and 87.02 bags respectively. The change in annual yield per farm for all the villages is statistically significant at $<0.05$ p-value.

This results is similar to the research findings of Shabu et al., (2011); Akighir and Shabu, (2011); Shabu, (2013); Iortyom et al., (2018); which posit that agricultural intervention projects could influence farmers to increase productivity through their intervention strategies which include but are not limited to farmer education, input subsidy, provision of farm infrastructure among others.

Impact of RED Hub Project on beneficiaries' Food Security status

In table 2, the results show that before the intervention of the RED Hub project none of the maize farmers were food secure, one person (0.5\%) was mildly food insecure. One hundred and four (52\%) maize farmers were mildly food insecure after the intervention of the project with a percentage change of $51.5 \%$. Ninety-seven $(48.5 \%)$ and 76 (38\%) maize farmers were moderately food insecure before and after RED Hub intervention respectively with a percentage change of $10.5 \%$. One hundred and two (51\%) and 13 (6.5\%) were severely food insecure before and after the projects' intervention with a change of $44.5 \%$.

In table 3 , the results reveal that there were more access and affordability of other food to meet maize farmers' nutritional needs after RED Hub project intervention. One hundred and sixty-nine (80.5\%) farmers were able to buy fruits as against 41 (20.5\%) before the intervention of the project with an increase of $60 \%$ affordability of fruits by benefitting maize farmers.

One hundred ninety-nine (99\%) farmers were able to buy bread after the project intervention as against 198 (94.8\%) with 4.2 percent change. Access to sugar increased by $22.3 \%$, Milk 4.2\%, Meat 29.3\%, Fish 37.1\%, Vegetables $27.1 \%$, Beans $22.7 \%$, Potatoes $15.4 \%$, Rice $41.2 \%$, Eggs $11 \%$. There was no increase in access to butter even after the intervention of RED Hub Project.

Agricultural programs and strategic plans have the potential to have significant effects on household food security (Ford and Beaumier, 2011). The study reveals as presented in Table 3 and Table 4 that before

Table 2. Changes in beneficiaries' food security before and after RED Hub Project

\begin{tabular}{|c|c|c|c|c|c|}
\hline \multirow[t]{2}{*}{ Variable } & \multicolumn{2}{|c|}{ Food Security Before } & \multicolumn{2}{|c|}{ Food Security After } & \multirow{2}{*}{$\begin{array}{l}\text { Percentage } \\
\text { Change }\end{array}$} \\
\hline & Frequency & Percentage & Frequency & Percentage & \\
\hline Food Secure & 0 & 0.0 & 7 & 3.5 & 3.4 \\
\hline Mildly Food Insecure & 1 & 0.5 & 104 & 52.0 & 51.5 \\
\hline Moderately Food Insecure & 97 & 48.5 & 76 & 38.0 & 10.5 \\
\hline Severely Food Insecure & 102 & 51.0 & 13 & 6.5 & 44.5 \\
\hline Total & 200 & 100 & 200 & 100 & 100 \\
\hline
\end{tabular}

Table 3. Beneficiaries' food affordability before and after RED Hub Project

\begin{tabular}{|c|c|c|c|c|c|c|}
\hline \multirow[t]{2}{*}{ Variables } & \multicolumn{2}{|c|}{ Before RED Hub Intervention } & \multicolumn{2}{|c|}{ After RED Hub Intervention } & \multirow{2}{*}{\multicolumn{2}{|c|}{$\begin{array}{l}\text { Percentage } \\
\text { Change }\end{array}$}} \\
\hline & Frequency & Percentage & Frequency & Percentage & & \\
\hline Bread & 198 & 94.8 & 199 & & 99 & 4.2 \\
\hline Milk & 155 & 77.5 & 154 & & 73.3 & -4.2 \\
\hline Sugar & 176 & 88 & 138 & & 65.7 & -22.3 \\
\hline Meat & 30 & 15 & 93 & & 44.3 & 29.3 \\
\hline Fish & 3 & 1.5 & 81 & & 38.6 & 37.1 \\
\hline Vegetable & 40 & 20 & 99 & & 47.1 & 27.1 \\
\hline Fruits & 41 & 20.5 & 169 & & 80.5 & 60.0 \\
\hline Beans & 7 & 3.5 & 55 & & 26.2 & 22.7 \\
\hline Potatoes & 13 & 6.5 & 46 & & 21.9 & 15.4 \\
\hline Rice & 11 & 5.5 & 98 & & 46.7 & 41.2 \\
\hline Butter & 18 & 9.0 & 18 & & 9.0 & 0 \\
\hline Eggs & 18 & 9.0 & 42 & & 20 & 11.0 \\
\hline
\end{tabular}


the intervention of the RED Hub Project none of the maize farmers were food secure but after the project's intervention, 104 (52\%) maize farmers benefitting from the project were mildly food insecure. This study affirms the fact that cereals are known to be the primary source of food as regards achieving food security in a country (Onasanya and Obayelu, 2016) of which maize is one of the most essential ingredients used as raw material for cereal in the world (Shiferaw et al., 2011). It has emerged from the work of Shiferaw et al., (2011) that maize accounts for the total of $73 \%$ and $64 \%$ of the demand for food in East Africa and South Africa as well as the Western and Central Africa (WCA) regions respectively.

Data by FAOSTAT, (2015) indicate that the major countries with high consumption of maize in the East and Southern African region are Zambia, Zimbabwe, Kenya, Burkina Faso, United Republic of Tanzania and Mozambique with 999, 743, 663, 596, 523 and 438 kcal/ capita/day respectively. In Tanzania, maize is consumed in all regions; it is the most produced crop (31\%) and the most consumed cereal crop, which accounts for more than $75 \%$ of national production. Muhihi et al., (2012), Suleiman and Rosentrater, (2015), place the annual per capita consumption of maize at an estimated to $128 \mathrm{~kg}$.

The results of this study also support the findings of United State Agency for International DevelopmentUSAID (2011), that the access to adequate food (Food Security) could be achieved by agricultural intervention on food production. Also, the report indicates that farmer incomes can increase as a result of the increase in productivity propelled by Agricultural projects.

This implies that there is access to healthy food as an effect of increased production which contributed to increased maize farmers' income that could afford other food options to complement the intake of maize which is the farmer's primary food readily available for consumption. The improved level of food security and nutrition of the maize farmers could be attributed to the effects that are associated with the fact that, increased food production in this case maize could lead to increased income and that in turn could empower the maize farmers to be able to afford other food options to complement their nutritional needs.

\section{Conclusion}

The findings on food security status of farmers into maize farming after the intervention of RED Hub project clearly show that there was an increase in maize production (Table 1) and more maize farmers that benefitted from the project are food secured after the intervention of the project. Their accessibility and affordability of other food options to complement their nutritional needs as depicts in table 4 is a clear validation. However, based on the findings on food security status, it was observed that there had been no intentionality in the design and execution of the RED Hub project to ensure that the benefitting maize farmers are food secure. Therefore, the study recommends that the project should consider a deliberate policy to include food security and nutritive benefits of maize farmers in the RED Hub strategy.

\section{References}

Abate, T., Fisher, M., Abdoulaye, T., Kassie, G. T., Lunduka, R., Marenya, P., and Asnake, W., (2017). Characteristics of maize cultivars in Africa: How modern are they and how many do smallholder farmers grow? Agriculture \& Food Security, 6(1), Pp.30.

Agriculture Special Report, (2013). Food Security Challenges in West Africa: A Focus on Agriculture. Availability West Africa Insight October, 2013

Aliber, M., and Hart, T. G. (2009). Should subsistence agriculture be supported as a strategy to address rural food insecurity? Agrekon, 48(4), Pp.434-458.

Assenga, E.A and Kayunze, K.A. (2016). Food Security Incidences Based on Dietary Energy Consumption, Dietary Diversity and Household Food Insecurity Access Scale in Chamwino District, Tanzania. International Journal of Asian Social Science, 6 (11) Pp.644 -658

Baird, S., McIntosh, B. and Ozler, M. (2009). Targeting in a Community-Driven Development Program: Applications and Acceptable Tanzania's TASAF. Washington, DC: World Bank.

Binswanger, M. H. P. and Jacomina, P. De Regt (2012). Scaling Up In Agriculture, Rural

Development and Nutrition: Moving Local-and CommunityDriven Development from

Boutique to Large Scale. Focus 19.Brief 3.June 2012. International Food Policy Research Institute.

Cochran, W.G. (1977). Sampling Techniques John Willey \& Sons, Inc. USA

Eastern Cape Rural Development Agency-ECRDA, 2013/14. Annual Report. Pp.3 www.ecrda.co.za/index.php/ publications

Dongier, P., Julie, V.D., Elinor, O., Andrea, R., Wendy, W., Anthony, B., Talib, E., and Margret, P. (2003). "Community Driven Development." In Poverty Reduction Strategy Paper Source book, Washington DC.

Etikan, I., Musa, S. A., and Alkassim, R. S. (2016). Comparison of convenience sampling and purposive sampling. American Journal of Theoretical and Applied Statistics, 5(1), Pp.1-4.

FAOSTAT, 2015. Food and Agricultural Organization of the United Nations. FAO Statistical

Database 2015. www.fao.org/publications

Ford, J.D., and Beaumier, M. (2011). Feeding the Family during times of stress: Experience and Determinants of Food Security in an Inuit Community. The Geographical Journal, 177(1), Pp.44-61

Iortyom, E.T., Sonwabo, P.M., and Nel, W. (2018). Analysis of the economic impact of Rural Enterprise Development Hub Project on maize farmers in Mqanduli, South Africa. Indian Journal of Agricultural Research, 52 (3), Pp.243-249

Israr, M., Yaseen, A., and Ahmad, S. (2017). Sustainable Rural Development and Livelihood Sources of the Rural Households in Mountainous Pakistan. American Journal 
of Rural Development. 5 (4) Pp. 97-105

Joseph, A.Y. (2014). Building Resilience, Reducing Vulnerability to Climate Change: Implications for Food Security in Ghana. Department of Geography and Resources Development, University of Ghana. http:// www.fesghana.org

Kwadwo, A. and Peter, H. (2012). Theories in Community Driven Development Operations:

A Case Study of Ghana Local Government System. European Journal of Business and Social Sciences, 1 (5), Pp.83-98

Matlou, C., Antwi, M. A., and Chagwiza, C. (2017). Determinants of maize farmers' adoption of Bt maize in Gauteng Province of South Africa. International Journal of Biotechnology, 14(3), Pp.231-244.

Muhihi, et al. (2012). Perceptions, Facilitators, and Barriers to Consumption of Whole Grain Staple Foods among Overweight and Obese Tanzanian Adults: A Focus Group Study. International Scholarly Research Network. Volume 2012, pp 7.

Ndleve, S., Musemwa, L., and Zhou, L. (2013). How Severe Hunger is amongst rural households of the Eastern Cape Province of South Africa. Journal of Economics and Sustainable Development, 4 (3), Pp.220-227.

Oladoja, M. A., and Adeokun, O. A. (2009). An Appraisal of the National Fadama Development Project (NFDP) in Ogun State, Nigeria. Agricultural Journal, 4(3), Pp.124129.

Olaniyan, A. B. (2015). Maize: Panacea for Hunger in Nigeria. African Journal of Plant Science, 9(3), Pp.155-174.

Onasanya, O. A. \& Obayelu O. A. (2016). Determinants of Food Security Status of Maize-Based Farming Households in Southern Guinea Savannah Area of Oyo State, Nigeria. Turkish Journal of Agriculture - Food Science and Technology, 4(5), Pp.411-417.

Pindiriri, C., Mumbengegwi, C., and Zhou, H. (2016).The impact of drought on technical efficiency of smallholder farmers in hurungwe, Zimbabwe. Botwana Journal of Economics, 14 (1), Pp.71-92

Poppy, G. M., Chiotha, S., Eigenbrod, F., Harvey, C. A., Honzák, M., Hudson, M. D., and Villa, F. (2014). Food security in a perfect storm: using the ecosystem services framework to increase understanding. Philosophical Transactions of the Royal Society of London B:Biological Sciences, 369(1639), 20120288.

Qongyo, L. (2015). ECRDAs approach to the application of the RED Hubs. Inkqubela Harvest Edition: August, 2015. Pp.8.

Ranum, P., Peña-Rosas, J. P., and Garcia-Casal, M. N. (2014). Global maize production, utilization, and consumption. Annals of the New York Academy of Sciences, 1312(1), Pp.105-112.

Shabu, T., Gyuse, T.T., Abawua, J.I., (2011). Economic Impact of Olam Out-Grower Programme on Rice Farming in Kaambe District of Guma Local Government, Benue State, Nigeria. International Journal of Humanities and Social Science, 1 (17), Pp.303-316

Shabu, T. (2013). Determinants of Resource Use Efficiency of Rice Farmers in Kaambe District of Guma Local Government Area of Benue State, Nigeria. World Journal of Agricultural Research, 1 (6), Pp.143-148.

Sharma, G., and Mehta, S. (2016). Trends, Growth and Instability in Area, Production and Productivity of Maize Crop across Regions in India. Productivity, 56(4), Pp.368.
Sharoni, U. H., Zenon, M., and Mbabazize, M. (2016). Assessment of the Effect of Community Empowerment Projects on Enhancing Poverty Alleviation in Rwanda. A Case

Study of Rubaya Demonstration Project. European Journal of Business and Social Sciences, 5 (1), Pp.321-346

Shoja, M. and Choolandimi, A.M. (2016). The Identification and Analysis of the Effects of the Rural Hadi Project in Rural Areas (Case Study: Julaki Rural District of Jayezan City in Omidiyeh). The IIOAB Journal. 7 (4), Pp.516-521

Sinyolo, S., Mudhara, M., \& Wale, E. (2016). The Impact of Social Grants on the Propensity and Level of Use of Inorganic Fertiliser among Smallholders in KwazuluNatal, South Africa. Agrekon, 55(4), Pp.436-457.

Smale, M., Byerlee, D. and Jayne, T. (2011). Maize Revolutions in Sub-Saharan Africa. The World Bank. Agriculture and Rural Development. USA.

Smit, P. R. (2016). Factors that influence the development of South African subsistence maize farmers into commercial farming units (Doctoral dissertation, North-West University (South Africa), Potchefstroom Campus).

Suleiman, R. A. and Rosentrater, K. A. (2015). Current Maize Production, Postharvest Losses.

and the Risk of Mycotoxins Contamination in Tanzania. Conference Proceedings and Presentations. New Orleans, Louisiana. July $26-29,2015$.

StatsSA. (2012). Income and expenditure of households: 2010/2011. Statistical release P0100. Statistics South Africa.www.statssa.gov.za/publications/statssa $\mathrm{PPN}=\mathrm{P} 0100 \& \mathrm{SCH}=5371$

Tesfahunegn, G. B., Mekonen, K., and Tekle, A. (2016). Farmers' perception on causes, indicators and determinants of climate change in northern Ethiopia: Implication for developing adaptation strategies. Applied Geography, 73(2016), Pp.1-12.

Trefry, A., Parkins, J. R., and Cundill, G. (2014). Culture and food security: a case study of homestead food production in South Africa. Food security, 6(4), Pp.555-565.

USAID (2011). Food Security Indicators for the Use in the Monitoring and Evaluation of Food Security Program, Washington DC, Economic Research Service.

World Bank (2013). Investment in Agricultural Water for Poverty Reduction and Economic Growth in SubSaharan Africa: Synthesis Report. 